\title{
Reduction of Liver Fibrosis After Treatment with Elbasvir/Grazoprevir in Patients with Hepatitis C Infection in Chronic Kidney Disease on Hemodialysis, a Quasi-Experimental Study
}

\author{
Bayu Laksono*, Nenny Agustanti**, Rudi Supriyadi*** \\ Muhammad Begawan Bestari**, Siti Aminah Abdurachman** \\ *Department of Internal Medicine, Faculty of Medicine \\ Universitas Padjadjaran/Hasan Sadikin General Hospital, Bandung \\ **Division of Gastroentero-hepatology, Department of Internal Medicine \\ Faculty of Medicine, Universitas Padjadjaran/Hasan Sadikin General Hospital Bandung \\ ***Division of Nephrology and Hypertension, Department of Internal Medicine \\ Faculty of Medicine, Universitas Padjadjaran/Hasan Sadikin General Hospital, Bandung
}

\section{Corresponding Authors :}

Bayu Laksono. Department of Internal Medicine, Faculty of Medicine, Universitas Padjadjaran/Hasan Sadikin General Hospital. Jl. Pasteur No. 38 Bandung Indonesia. Phone/facsimile: +62-22-2034953/55; Facsimile: +62-22-2032216.E-mail: bayulaksono819@gmail.com

\begin{abstract}
Background: Approximately 5-60\% of hemodialysis patients have comorbid of hepatitis $C$ virus (HCV) infection. The survival rate of hemodialysis patients $\mathrm{HCV}$ is lower than those without HCV due to the risk of liver fibrosis and cardiovascular disease. The combination of Elbasvir and Grazoprevir is the drug of choice for these patients with HCV genotype 1 and 4 which mainly inherited in populations in Indonesia. However, a high cost is required for this genome testing. Eradication of HCV might reduce liver fibrosis. One of the methods to evaluate liver fibrosis is by using aspartate aminotransferase to platelet ratio index (APRI) score. The aim of this study is to assess liver fibrosis using APRI score after Elbasvir/Grazoprevir therapy completion.

Method: This was a quasi-experimental study without a control group which conducted during April-November 2019 in Dr. Hasan Sadikin Hospital, Bandung. Patients with reactive anti HCV, detected HCV RNA without genotype test, and sustained virological response (SVR) 12 achieved were included. APRI score and HCV RNA tests were performed before and after 12 weeks end of therapy (SVR12). The data were analyzed using paired T-test at a 95\% confidence level.

Results: Approximately 30\% of hemodialysis patients had HCV infection. A total of $37 \mathrm{HCV}$ patients in the hemodialysis unit were given Elbasvir/Grazoprevir for 12 weeks. The APRI score before and after 12 weeks after therapy were 0.336 and $0.270(p=0.002)$ respectively.

Conclusion: The combination of Elbasvir/Grazoprevir might reduce the degree of liver fibrosis based on APRI score from 0.336 to 0.270 in HCV patients with chronic kidney disease on hemodialysis
\end{abstract}

Keywords: aspartate aminotransferase to platelet ratio index (APRI), Elbasvir, Grazoprevir, hemodialysis, Hepatitis C virus (HCV) 


\section{ABSTRAK}

Latar belakang: Sekitar 5-60\% pasien hemodialisis terinfeksi virus Hepatitis C (HCV). Tingkat kelangsungan hidup pasien hemodialisis dengan hepatitis $C$ lebih rendah daripada pasien hemodialisis tanpa hepatitis $C$ karena risiko fibrosis hati dan penyakit kardiovaskular. Kombinasi Elbasvir dan Grazoprevir adalah obat pilihan untuk pasien ini. Eradikasi HCV dapat mengurangi fibrosis hati. Skor APRI dapat mengevaluasi fibrosis hati. Tujuan dari penelitian ini adalah untuk menilai fibrosis hati menggunakan skor Aspartate aminotransferase to platelet ratio index (APRI) setelah terapi Elbasvir/Grazoprevir.

Metode: Penelitian ini merupakan penelitian kuasi eksperimental tanpa kelompok kontrol selama AprilNovember 2019 di Rumah Sakit Dr. Hasan Sadikin, Bandung. Pasien dengan Anti HCV reaktif, HCV RNA terdeteksi tanpa diperiksa genotip dan sustained virological response (SVR) 12 tercapai dimasukkan dalam kriteria inklusi. Skor APRI dan tes HCV RNA dilakukan sebelum dan setelah 12 minggu akhir terapi (SVR12). Data dianalisis menggunakan paired T-test pada 95\% confidence level.

Hasil: Dari 30\% pasien hemodialisis diketahui terinfeksi HCV. Sejumlah 37 pasien HCV dengan HCV RNA terdeteksi di unit hemodialisis diberikan Elbasvir/Grazoprevir selama 12 minggu dan SVR12 tercapai. Skor APRI sebelum terapi adalah 0,336 dan 12 minggu setelah terapi selesai adalah 0,270 ( $p$-value = 0,002).

Simpulan: kombinasi Elbasvir/Grazoprevir dapat menurunkan tingkat fibrosis hati berdasarkan skor APRI dari 0,336 menjadi 0,270 pada pasien hepatitis $C$ dengan gagal ginjal dalam hemodialisis.

Kata kunci: aspartate aminotransferase to platelet ratio index (APRI), Elbasvir, Grazoprevir, hemodialisis, virus hepatitis $C$

\section{INTRODUCTION}

Prevalence of Hepatitis C (HCV) in routine hemodialysis patients ranges from $5-60 \%$ depends on the hemodialysis site. HCV contributes on decreasing the survival rate in hemodialysis patients. The mortality rate for patients on hemodialysis with $\mathrm{HCV}$ is about 1.35 times higher compared to those without HCV. The survival rates of HCV patients on hemodialysis therapy for 8 years and those without $\mathrm{HCV}$ are around $32 \%$ and $52 \%$, respectively $(p=0.03))^{1-3}$

$\mathrm{HCV}$ increases inflammation and alters the nutritional status in chronic kidney disease (CKD) patients. Liver fibrosis is one of the hepatic symptoms that might arise. The degree of liver fibrosis needs to be assessed routinely as a response to the therapy in HCV patients. ${ }^{4}$ The gold standard to evaluate the degree of liver fibrosis is through liver biopsy. However, considering the high risk of bleeding, non-invasive method is preferred. The cheapest and Easiest test to do for the non-invasive method is through calculating aminotransaminase to platelet ratio index (sensitivity $91.9 \%$ and spesificity $90.3 \%)^{1,5,6}$

The treatment of HCV is focusing on preventing further complications such as fibrosis, cirrhosis and carcinoma. It is crucial to treat $\mathrm{HCV}$ especially in patients with severe fibrosis, hepatitis B, and HIV coinfection, organ transplant candidates, organ damage, high risk of transmission, and metabolic syndrome. ${ }^{7}$ The presence of a potential direct acting antiviral therapy such as Elbasvir/Grazoprevir, which was proven to be safe from clinical trials (excretion via urin is low and no need adjustment dose), shed a light for $\mathrm{HCV}$ treatment in CKD patients. ${ }^{8}$ Nevertheless, reports on changes in liver fibrosis after Elbasvir/Grazoprevir therapy in pan-genotype $\mathrm{HCV}$ patients with chronic kidney failure in routine hemodialysis is still limited. ${ }^{9}$ This study aimed to provide data regarding the efficacy of Elbasvir/Grazoprevir therapy by evaluating changes in liver fibrosis through the APRI score.

\section{METHOD}

This quasi-experimental study was conducted in the hemodialysis unit of Dr. Hasan Sadikin Hospital in April - October 2019. All HCV patients with chronic kidney failure on routine hemodialysis who received Elbasvir/Grazoprevir therapy were monitored. Patients over 18 years of age on routine hemodialysis for at least 3 months with positive HCV RNA before treatment and accomplished sustained virological response (SVR) for 12 weeks were included. While those with HIV coinfection, autoimmune, cancer, blood disorders such as leukemia, thrombocytopenia, and Evan's syndrome, patients with obstructed gallbladder, those who consume drugs that might induce thrombocytopenia, and those who were lost to follow up were excluded. APRI scores were calculated and HCV RNA tests were conducted 


\section{5 patients with chronic renal failure on hem odialysis with positive anti-HCV}

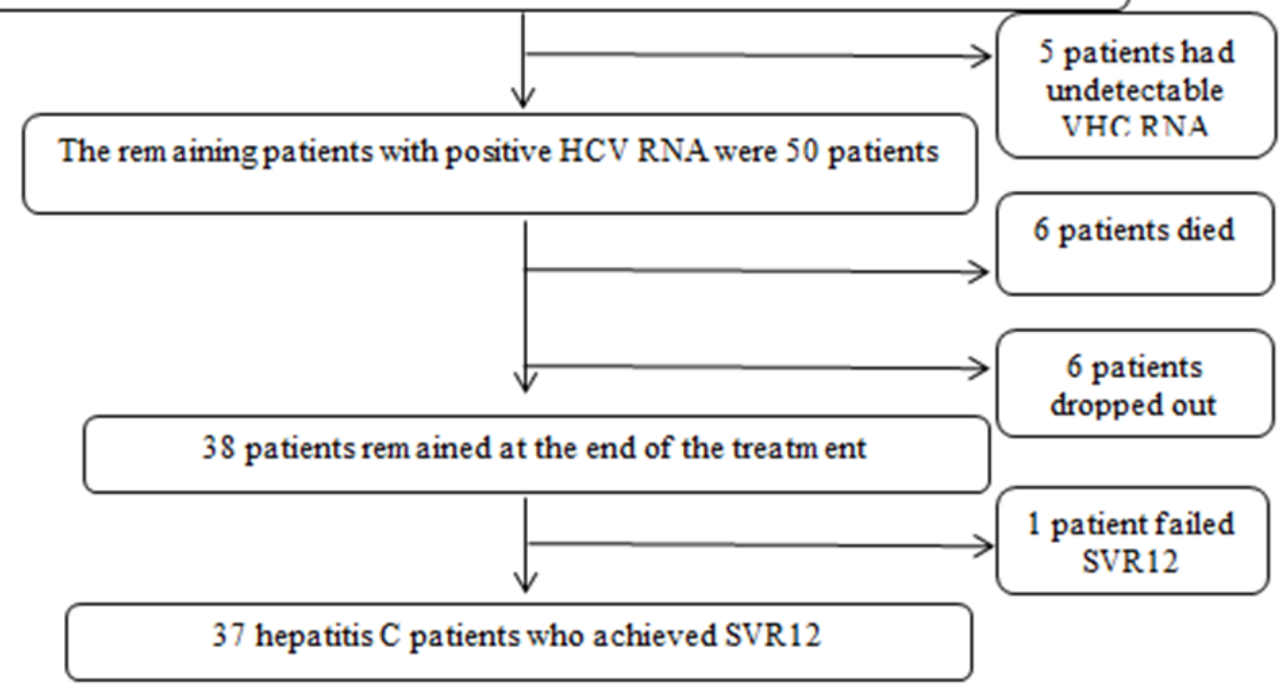

Figure 1. Diagram of study

before and after 12 weeks end of therapy (SVR12). Serum AST, ALT, thrombocytes and HCV-RNA were tested for baseline data. Serum AST, ALT, thrombocyte, and HCV-RNA measurements were repeated at week 12 after end of therapy. The outcome was the decrease of APRI score at 12 weeks after end of therapy. Side effects were also reported. Written informed consent was obtained from the subjects. The study was approved by the ethic committee in Hasan Sadikin Hospital and the research was conducted in accordance with the tenets of the Declaration of Helsinki.

Data analysis was performed using the statistical product and service solution (SPSS) program for windows version 22.0 Armomk,NY: IBM Corp. The normality of the distribution of the data was assessed using Shapiro Wilk Test and then further analyzed using paired T test. Significant differences were defined as $\mathrm{p}<0.05$ at a $95 \%$ confidence level.

The study was approved by the ethic committee and the research was conducted in accordance with the tenets of the Declaration of Helsinki

\section{RESULTS}

Among HCV patients who underwent hemodialysis in Dr. Hasan Sadikin Hospital from April to October 2019, a total of 55 patients met the inclusion criteria. Five patients had undetectable VHC RNA results. While six other participants died, six of them stopped the treatment. Out of 50 patients enrolled in the study, only 38 participants who were able to finish the protocol. However, one person failed to achieve SVR12 and excluded (Figure 1)
The baseline clinical characteristics of the study participants is shown in Table 1. Most of the subjects were male $(51.4 \%)$ with the mean age of 49 years old. These patients had an average length of hemodialysis duration of 6 years. The average patient's body mass index (BMI) in the normal category was $23.5 \%(17,8$ $-33,3 \%)$. The preliminary value of liver function test before therapy showed the level of albumin was 3.39 $\mathrm{gr} / \mathrm{dL}$, bilirubin total $0.449 \mathrm{gr} / \mathrm{dL}$ and the platelet counts $183.81 \pm 50.544 \times 103 / \mathrm{mm}^{3}$.

Table 1. Baseline characteristic of the study

\begin{tabular}{|c|c|}
\hline Baseline characteristic & $\mathrm{n}=37$ \\
\hline Age (years), mean (SD) & $49(11)$ \\
\hline \multicolumn{2}{|l|}{ Sex, n (\%) } \\
\hline Male & $19(51,4)$ \\
\hline Female & $18(48,6)$ \\
\hline Length of hemodialysis (years) & $6(3)^{*}$ \\
\hline Body mass index/BMI $\left(\mathrm{kg} / \mathrm{m}^{2}\right)$ & $23,5(17,8-33,3)^{\star *}$ \\
\hline \multicolumn{2}{|l|}{ Cause of CKD, n (\%) } \\
\hline Diabetes Mellitus & $3(8,1)$ \\
\hline Hypertension & $27(72.9)$ \\
\hline Urolithiasis & $3(8.1)$ \\
\hline Others & $4(10.8)$ \\
\hline Hepatitis C virus Ribonucleic acid/HCV & $1.13(0.010-8.790)^{\star *}$ \\
\hline \multicolumn{2}{|c|}{ RNA $\left(x 10^{6}\right)$} \\
\hline Aspartate aminotransferase/AST (IU/L) & $20(6-606)^{* *}$ \\
\hline Alanine aminotransferase/ALT (IU/L) & $25(12-571)^{\star *}$ \\
\hline Albumin, mean (min-max) & $3,39(2,80-3,90)^{* * *}$ \\
\hline Bilirubin, mean (min-max) & $0,449(0,289-1,085)^{* * *}$ \\
\hline Platelet $\left(/ \mathrm{mm}^{3}\right)$, median (min-max) & $\pm 50,544 \times 10^{3 * *}$ \\
\hline
\end{tabular}

Several tests including HCV RNA, platelet counts, ALT, AST, urea, and creatinine were evaluated before and after therapy. The differences obtained between the study were pointed out in Table 2. Meanwhile, evaluation of the changes in liver fibrosis before and 
after the therapy, as shown in Table 3, revealed a significant decrease in APRI score after the therapy $(\mathrm{p}<0.05)$. The median APRI score before therapy was 0.336 which decline to 0.270 . The changes were pointed out in table 3

\section{DISCUSSION}

In our study, 55 patients out of 164 total patients $(33 \%)$ in hemodialysis unit had positive anti-HCV results. This percentage is much higher than that in some countries which capable in suppressing the diseases. For example, in Australia, the number lessen from $48.6 \%$ to $2.9 \%$ in 2015 , In Japan, from $42.9 \%$ to $2.9 \%$, and in the United States from $62.6 \%$ to $4.8 \%{ }^{10}$ In this study, 19 subjects (51.4\%) were male. This is in accordance with the epidemiological data obtained from 3 hospitals in Jakarta, Indonesia that showed 75 of $133 \mathrm{HCV}$ patients in routine hemodialysis were male. ${ }^{7}$ Research by Jasuja et al also showed that the gender of $\mathrm{HCV}$ patients on hemodialysis $65 \%$ were dominantly male (77/119 patients). ${ }^{11}$ As in the TRIO and study by Khan et al $63 \%$ and $57 \%$ of patients involved were also male patients, respectively. ${ }^{12}$ The reasonable causes might due to the increased risk of exposure to $\mathrm{HCV}$ through unclean hair shaving communities, unsterile or contaminated shavers, and the risk of sexual relations outside of marriage. ${ }^{13}$

The mean age of $\mathrm{HCV}$ patients with kidney failure in this study was 49 years old (SD: 11). This result is not much different from a study in India which found that the average age was $53.18 \pm 15.1$ years. ${ }^{11}$ Other study showed that $49 \%$ of HCV patients in hemodialysis were aged $41-60$ years. ${ }^{14}$ Research in Jakarta, Indonesia showed $72 \%$ of $\mathrm{HCV}$ patients in hemodialysis were patients over 40 years old. Older people have a higher risk because their health and immune structures are more fragile than younger ages. In line, the study conducted by Becker concluded that age at diagnosis over 40 years old was an independent risk factor for liver fibrosis. ${ }^{7,15}$

The average length of hemodialysis in this study was 6 years. In a study conducted by Chigurapati et al showed the prevalence of the duration in hemodialysis in anti-HCV patients was $13.3 \%$ with a duration of less than 1 year and $69.9 \%$ with the duration more than 10 years. ${ }^{14}$ This shows the relationship between the duration of hemodialysis with the risk of HCV. The $\mathrm{HCV}$ virus cannot penetrate the pores of the membrane dialyzer. Potential sources of nosocomial transmission might include the reusing of dialyzers, poor infection control, internal hemodialysis monitor contamination, environmental aerosols, contaminated droplets, or transfusions of contaminated blood products. ${ }^{15-17}$

In this study, platelet count obtained before therapy was $183.081 \pm 50.544$ and after therapy was 186.595 $\pm 50.956(\mathrm{p}=0.491)$. The Suda et al study showed initial data of $13.8 \pm 6 \times 10000 / \mu \mathrm{L}$ and there were no significant changes before and after therapy. ${ }^{18} \mathrm{~A}$ study conducted by Nielsen mentioned an increase in platelet counts after $\mathrm{HCV}$ therapy without comorbid by $1.66 \times 105 / \mu \mathrm{L}$ to $1.70 \times 105 / \mu \mathrm{L}$ with $\mathrm{p}$-value $0.033 .{ }^{19}$ In a study conducted by Orasan et al. median platelet value of $155 \times 103 / \mathrm{mm}^{3}$ in $\mathrm{HCV}$ patients on dialysis was obtained. ${ }^{20} \mathrm{~A}$ similar finding was recorded by Ando et al who obtained significantly lower platelet counts $(\mathrm{p}<0.01)$ in dialysis patients with hepatitis $\mathrm{C}$ $\left(145,300 \pm 38,300 / \mathrm{mm}^{3}\right)$ compared to dialysis patients without hepatitis C $\left(195,600 \pm 51,400 / \mathrm{mm}^{3}\right)$. This study also found megakaryopoiesis which showed platelet reduction depends on the onset of dialysis, peripheral destruction, and sequestration in patients with $\mathrm{HCV}$ infection contributing to the etiology of thrombocytopenia. ${ }^{21}$ Other allegations that support

Table 2. Differences in hepatitis c virus ribonucleic acid (HCV RNA), platelet counts, alanine aminotransferase (ALT), aspartate aminotransferase (AST), urea, creatinine before and after therapy

\begin{tabular}{llll}
\hline \multirow{2}{*}{ Variable } & Test & After therapy & \\
\cline { 2 - 4 } & Before therapy & 0 & $<0,001^{\mathrm{b*}}$ \\
\hline HCV RNA $\left(\times 10^{3}\right)$ & $497(0,010-8.790)$ & $186.595 \pm 50.956(5.12-21.54)$ & $0,491^{\mathrm{a}}$ \\
Platelet $\left(/ \mathrm{mm}^{3}\right)$ & $183.081 \pm 50.544(7.11-21.14)$ & $0,002^{\mathrm{b*}}$ \\
AST & $20(6-606)$ & $17(5-38)$ & $<0,001^{\mathrm{b*}}$ \\
ALT & $25(12-571)$ & $15(9-32)$ & $0,718^{\mathrm{b}}$ \\
Urea & $143,7(60,6-298,9)$ & $147,0(49,0-213,0)$ & $0,782^{\mathrm{a}}$ \\
Creatinine & $13,67 \pm 3,36$ & $13,50 \pm 3,90$ & 0 \\
\hline
\end{tabular}

Note: Analyzed using ${ }^{\mathrm{T} T}$ test and ${ }^{\mathrm{b}}$ Wilcoxon

Table 3. Differences aspartate aminotransferase to platelet ratio index (APRI) Score before and after therapy

\begin{tabular}{|c|c|c|c|}
\hline \multirow[b]{2}{*}{ Variable } & \multicolumn{2}{|l|}{ Time of test } & \multirow[b]{2}{*}{$p$} \\
\hline & $\begin{array}{l}\text { Pre } \\
\text { Median (min-max) }\end{array}$ & $\begin{array}{l}\text { Post } \\
\text { Median (min-max) }\end{array}$ & \\
\hline $\begin{array}{l}\text { Aspartate aminotransferase to platelet ratio } \\
\text { index (APRI) score }\end{array}$ & $0,336(0,079-8,068)$ & $0,270(0,066-0,695)$ & $0,002^{*}$ \\
\hline
\end{tabular}


the theory are the increase in the number of absolute immature platelets, fraction of immature platelets, and the increase of thrombopoietin levels at three hours after hemodialysis. Activation of complement during hemodialysis increases the consumption of platelets and the release of immature platelets from bone marrow. ${ }^{20}$

The Median AST and ALT in this study obtained before therapy were 20U/L and ALT 25U/L and after therapy was $17 \mathrm{U} / \mathrm{L}$ and $15 \mathrm{U} / \mathrm{L}(\mathrm{p}<0.005)$. A study in Jakarta, Indonesia showed that there were differences in AST values between patients with significant fibrosis and patients with non significant fibrosis with a median of $28 \mathrm{U} / \mathrm{L}$ and $18 \mathrm{U} / \mathrm{L}$. AST values do not escalate the risk of liver fibrosis. AST values are indirectly related to liver fibrosis in patients with uremia. Another study by Becker et al mentioned AST as a predictor of liver fibrosis in hemodialysis. ${ }^{7,15}$ Also, in a study conducted by Huynh mentioned that in the second week of therapy, all patients reduced HCV RNA to < $700 \mathrm{IU} / \mathrm{mL}$ and $45.9 \%$ of HCV were not detected, this was related to ALT normalization of $85.5 \%$, AST of $83.9 \%$ and $77.4 \%$ normalizing both. At 12 weeks and 24 weeks after completion of therapy $90.8 \%$ and $94.8 \%$ of AST and ALT were normalized and improvement HCV RNA clearance. ${ }^{22}$

The average value of HCV RNA in this study was $1.13 \mathrm{IU} / \mathrm{mL}(0.010-8.790) \times 106 \mathrm{IU} / \mathrm{mL}$. HCV RNA might decrease during the hemodialysis session. HCV virus absorption into the dialysis membrane, virus destruction during hemodialysis, and rare conditions might happen due to $\mathrm{HCV}$ transfer through dialysate. ${ }^{23}$ In a study conducted by Baedalamnti et al, a decrease in HCV RNA value after hemodialysis were found (before hemodialysis, $824 \pm 234 \times 10^{3}$; after hemodialysis, 633 $\pm 178 \times 10^{3} ; 24$ hours after hemodialysis, $758 \pm 213 \times$ $10^{3}$; and 48 hours after hemodialysis, $776 \pm 226 \times 10^{3}$ copies $/ \mathrm{mL} ; \mathrm{p}=0.005) .{ }^{24}$ This is reason for HCV RNA testing should be tested prior to a dialysis procedure. ${ }^{24}$ In the C-Surfer study, the number of patients with HCV RNA $<800,000 \mathrm{vs}>800,000 \mathrm{IU} / \mathrm{mL}$ was $43.6 \%$ vs $57.4 \%{ }^{8}$ The relationship between HCV genotype and HCV RNA is still controversial although in some studies the high titer of viremia is associated with the degree of hepatic impairment while others do not find a histological correlation or aminotransaminase activity. In a study by Chakravarti, genotype 1 patients had a higher viral load than genotypes 2 and $3 .^{25}$

The success rate of Elbasvir/Grazoprevir therapy in $\mathrm{HCV}$ patients with chronic kidney failure in routine hemodialysis reaches $97 \%$. In a study conducted by
Flamm et al in the United States, the achievement of SVR12 in HCV patients with stage 4 and 5 kidney failure reached $99 \%$. Another explanation that can be resulted in failure of therapy is NS5A resistance which in this study is incomplete. ${ }^{12}$ A Japanese study conducted by Suda et al showed that SVR12 in patients with HCV genotype $1 \mathrm{~b}$ in hemodialysis reached $95.7 \%$. In this study patients who failed to achieve SVR were patients who had a history of treatment with Daclatasvir and Asunaprevir. ${ }^{18}$ The C-Surfer study the evaluation and efficacy of $50 \mathrm{mg}$ elbasvir and 100 mg grazoprevir for 12 weeks in genotype 1 with $99 \%$ SVR12. The cause of therapy failure is likely due to the presence of NS5A resistance and is recommended for examination before therapy. ${ }^{8}$ In the study of the TRIO network, reached SVR12 in HCV patients counted $89 \%$ in genotype 1 and $91 \%$ in genotype $4 .{ }^{12}$ In this study there were $3 \%$ whose SVR did not achieve. This is possible because in this study genotype examination was not carried out so it might not be suitable for the genotype that can be treated by Elbasvir/Grazoprevir while this drug can only be given for genotypes 1 and 4 and there was no examination of resistance to NS5A. This study is using the flow as explained in figure 2.

In this study, it was found that 36 of 37 patients had an APRI score $<1$ and 1 patient had an APRI value $\geq 1$. The median APRI in this study before therapy was 0.336 and after therapy was 0.270 . One patient with an APRI value $\geq 1$ just before therapy experienced an improvement in APRI to $<1$ after administration of Elbasvir/Grazoprevir therapy. This research is one of the first studies to assess the effect of reducing liver fibrosis based on APRI scores after Elbasvir/Grazoprevir therapy in Indonesia. In the TRIO network study, intent-to-treat treatment obtained after administration of Elbasvir/ Grazoprevir for 12 weeks in F4 fibrosis patients reached $87 \%$ and F0-F3 reached $87 \%$, while Elbasvir/Grazoprevir/Ribavirin administration reached $100 \%$ for improvement to lower fibrosis degree. The administration of Elbasvir/Grazoprevir for 16 weeks in patients with F4 fibrosis reaches $100 \%$ and $\mathrm{F} 0-\mathrm{F} 3$ reaches $67 \%{ }^{12}$ Low APRI score in this study can be caused by this subject does not yet experienced liver fibrosis or low aminotransferase value in chronic kidney disease on hemodialysis patients. Aminotransferase values are in the upper limit but within the normal range and are still higher than non-HCV patients with hemodialysis. Some other data that are still being debated include vitamin B6 deficiency, reduction associated with dialysis, and increased IFN production and lymphocyte 
activation. Another suspicion is the high metabolic activity of high homocysteine in hemodialysis patients and low correlation with AST. There are differences in study results, namely data on increasing serum ALT/ AST values after dialysis versus pre-dialysis. Other data states there is no difference before and after hemodialysis. ${ }^{26-28}$

The C-Coral study found the efficacy of Elbasvir/ Grazoprevir in HCV patients without comorbidities or other co-infections which reached SVR12 was 94.4\%. In HCV patients without cirrhosis, the SVR12 reached $94.7 \%$ and in $\mathrm{HCV}$ patients with cirrhosis, it reached $93.3 \% .{ }^{29} \mathrm{C}$-Surfer study conducted in the HCV population with kidney disease found the success rate of SVR12 therapy in HCV patients without cirrhosis reached $99.1 \%$ and with cirrhosis reached through $100 \%$. There are also data on HCV patients with stage 4 kidney failure with SVR 12 reaching $100 \%$ and chronic stage 5 kidney failure reaching $98.9 \%$ (98/99 patients). This C-Surfer study did not discuss how it improved the fibrosis or cirrhosis of the liver in the patients. ${ }^{8}$

A study conducted by Knop et al showed the reduction in liver stiffness from the baseline data (median, $32.5(9.1-75) \mathrm{kPa}$ ) to the end of the therapy (median, $21.3(6.7-73.5) \mathrm{kPa} ; \mathrm{p}<0.0001)$ and on SVR $2421.2(5.4-70) \mathrm{kPa} ; \mathrm{P}<.0001)$. Around 44 out of 50 patients $(88 \%)$ experienced the improvement in liver stiffness in SVR24 and around 23 out of 50 patients (46\%) experienced improvement in more than $30 \%$ in SVR24. In the AST examination, AST value before treatment median is $71(17-254)$ and SVR24 is 28 (17-96IU/L). APRI examination was carried out at the beginning of the study and the median APRI score was $2.5(0.3-15)$ and at SVR 24 the median result was $0.9(0.2-4.4)$ with a p-value of 0.0001 . Decreased in liver fibrosis is thought to be based on 2 phases namely the first phase, the decrease in stiffness, can be assumed to be more influenced by a reduction in necroinflammatory activity, while the second phase may be more affected by fibrosis regression. ${ }^{30,31}$ In a review done by Meer et al, a histological study of the results of 4 large prospective studies in patients underwent liver biopsy after 24 weeks after discontinuation of IFN therapy in patients with significant fibrosis who did not achieve SVR showed stable liver disease, whereas patients with SVR results had estimated a negative annual rate of progression of fibrosis $(-0,591)$ indicates regression of fibrosis. The results obtained are that almost $50 \%$ of 153 cirrhosis patients get Metavir results less than F4 in post-treatment liver biopsy. Scientific reasons that support this theory are the presence of anti-inflammatory effects, antifibrosis, suppression of the release of profibrogenic cytokines such as transforming growth factor $1 \beta$, hyaluronic acid, and procollagen III. ${ }^{32,33}$

Research conducted by Chen et al also found

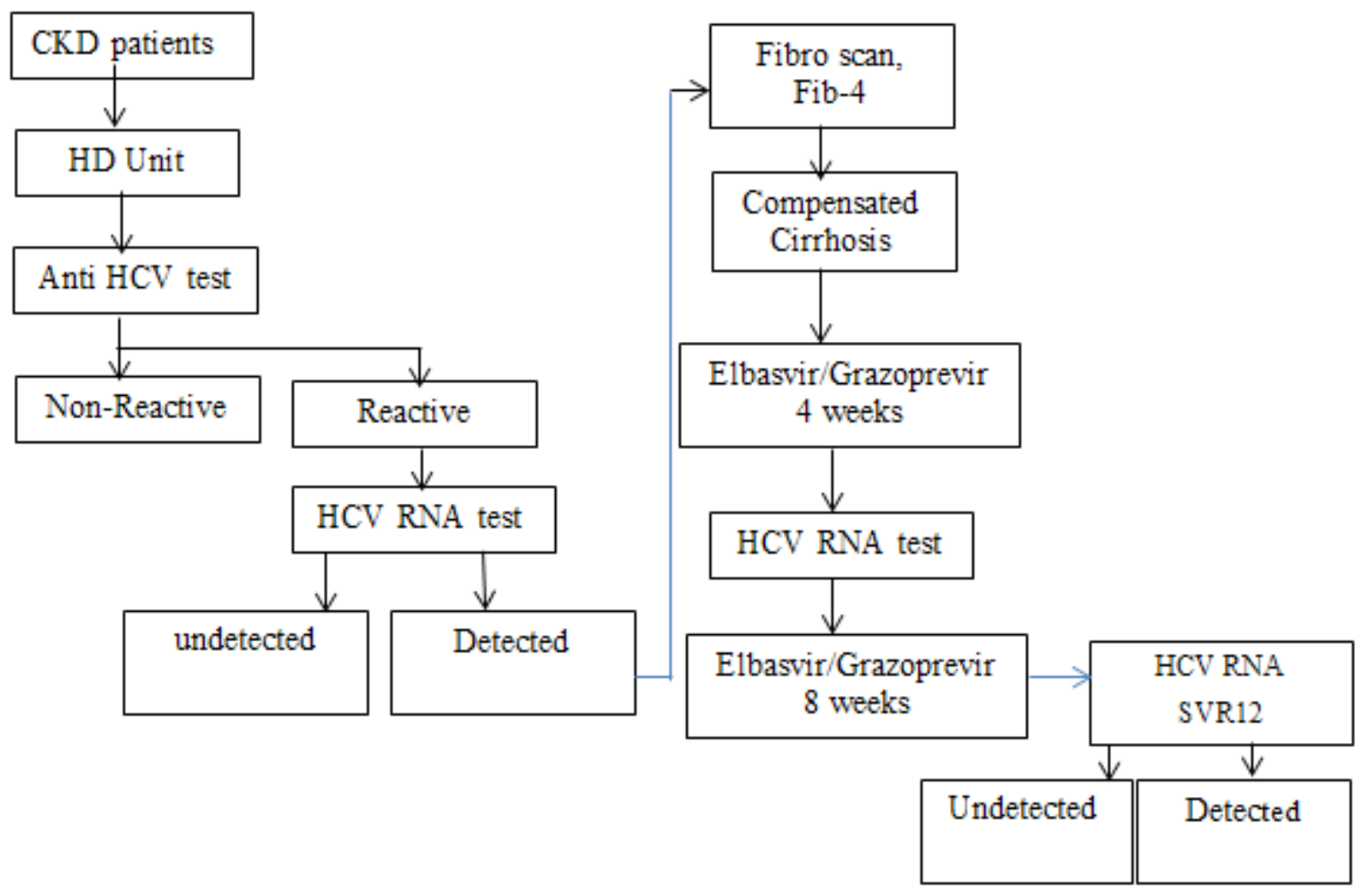

Figure 2. Elbasvir Grazoprevir Algorithm on genotype 1 dan 4 
that the progression of liver fibrosis after 10 years of completion of therapy showed 7\% progression of liver fibrosis in patients who achieved SVR compared to $30 \%$ in patients who did not achieve SVR. This is also supported by research by Shiha et al in 2,326 patients who achieved SVR during the 2015-2017 period in Egypt. He found that $\mathrm{F} 4$ patients experienced a decrease of 2 staging to $\mathrm{F} 2$ by $21.8 \%$, to $\mathrm{F} 3$ by $27.3 \%$ and remained to F4 by $508 \%$. F3 patients became F0-F1 by $26.5 \%$, became F2 $30.6 \%$ and remained F3 by $31.5 \%$. This is possible because of the presence of necro-inflammatory activity, especially in early cirrhosis. In the final stages of fibrosis, collagen crosslinking is found, the accumulation of high density collagen fibrillar and transglutaminase tissue makes the collagen fiber insensitive to enzyme degradation. . $^{31,34,35}$

As limitation this study did not use histopathological examination as the gold standard and transient elastography determine the degree of liver fibrosis. This study did not also test HCV genotype because high cost.

\section{CONCLUSION}

As a conclusion, Combination Elbasvir/Grazoprevir is proven effective in reducing the level of liver fibrosis based on APRI scores in HCV patients with chronic kidney disease on hemodialysis.

\section{ACKNOWLEDGMENT}

BL, NA, RS, BB and SA conceived and designed the study. BL acquire the data. All authors contributed to the writing of the manuscript.

\section{REFERENCES}

1. Azmi AN, Tan S-S, Mohamed R. Hepatitis C and kidney disease: An overview and approach to management. World J Hepatol 2015;7:78-92.

2. PPHI. Konsensus Penatalaksanaan Hepatitis C di Indonesia. Jakarta.2017.

3. Barsoum RS, William EA, Khalil SS. Hepatitis C and kidney disease: A narrative review. Journal of advanced research 2017;8:113-30.

4. Lydia A, Supriyadi R, Lestari D, Sanitiyoso A, Alvani R, Hasan I, et al. Konsensus Nasional Penatalaksanaan Hepatitis C Pada Penyakit Ginjal Kronik Di Indonesia. Jakarta: PPHI dan PERNEFRI; 2019.p.23.

5. Florian b. Liver fibrosis: difficulties in diagnostic and treatment: a review. Gastroenterology Medicine \& Research 2017;1:1-8.

6. Rajesh Kumar W, Muhammad Manzoorul Haque, Nasir Hassan Luck, Abbas Ali Tasneem, Zaigham Abbas, Muhammad Mubarak. Diagnostic accuracy of aspartate aminotransferase to platelet ratio index and fibrosis 4 scores in predicting advanced liver fibrosis in patients with end-stage renal disease and chronic viral hepatitis: Experience from Pakistan. J Transl Int Med 2018;6:38-42.

7. Lydia A, Gani RA, Rinaldi I. Liver fibrosis of hepatitis $C$ virus infection in routine hemodialysis patients in Indonesia. Med J Indones 2019;28:375-9.

8. Roth D, Nelson DR, Bruchfeld A, Liapakis A, Silva M, Monsour H Jr, et al Grazoprevir plus elbasvir in treatmentnaive and treatment-experienced patients with hepatitis $\mathrm{C}$ virus genotype 1 infection and stage 4-5 chronic kidney disease (the C-SURFER study): a combination phase 3 study. Lancet 2015;17:1537-45.

9. Nelson DR, Cooper JN, Lalezari JP, Lawitz E, Pockros PJ, Gitlin N, et al. All-oral 12-week treatment with daclatasvir plus sofosbuvir in patients with hepatitis $\mathrm{C}$ virus genotype 3 infection: ALLY-3 phase III study. Hepatology 2015;61:1127-35.

10. Yan J, Edmund Huang, Alireza Mehrnia, Mandana Kamgar, Phuong Pham, Olapluwapo Ogunorunyinka, et al. Can aminotransferase-to-platelet ratio index and other noninvasive markers effectively reduce liver biopsies for renal transplant evaluation of hepatitis $\mathrm{C}$ virus-positive patients? Nephrology Dialysis Transplantation 2014;29:1247-52.

11. Jasuja S, Gupta AK, Choudhry R, Kher V, Aggarwal DK, Mishra A, et al. Prevalence and associations of hepatitis C viremia in hemodialysis patients at a tertiary care hospital. Indian J Nephrol 2009;19:62-7.

12. Flamm SL, Bacon B, Curry MP, Milligan S, Nwankwo CU, Tsai N, et al. Real-world use of elbasvir-grazoprevir in patients with chronic hepatitis $\mathrm{C}$ : retrospective analyses from the TRIO network. Aliment Pharmacol Ther 2018;47:1511-22.

13. Khan S, Attaullah S, Ali I, Ayaz S, Naseemullah, Khan SN, et al. Rising burden of Hepatitis C Virus in hemodialysis patients. Virology Journal 2011;8:438.

14. Mitchell O, Feldman DM, Diakow M, Sigal SH. The pathophysiology of thrombocytopenia in chronic liver disease. Hepat Med 2016;8:39-50.

15. Mohamed A, Sqalli T, Tazi N, El Youbi R, Chaouch S, Aqodad $\mathrm{N}$, et al. Non-invasive assessment of liver fibrosis in chronic hemodialysis patients with viral hepatitis C. Pan African Medical Journal. 2015;22:273.

16. Speranta. I, Razvan Cerban, Corina Pietrareanu, Carmen Ester, Razvan Iacob, Cristian Gheorghe, et al. 100\% Sustained Virological Response and Fibrosis Improvement in Real-Life Use of Direct Acting Antivirals in Genotype-1b Recurrent Hepatitis C following Liver Transplantation. J Gastrointestin Liver Dis 2018;27:139-44.

17. WHO. Hepatitis C. In: WHO, editor. 2009.

18. Mulyanto. Viral Hepatitis in Indonesia: Past, Present, and Future. Euroasian journal of hepato-gastroenterology 2016;6:65-9.

19. Nielsen NS, Jespersen S, Gaardbo JC, Arnbjerg CJ, Clausen $\mathrm{MR}, \mathrm{Kjær} \mathrm{M}$, et al. Impaired platelet aggregation and rebalanced hemostasis in patients with chronic Hepatitis C Virus infection. Int J Mol Sci 2017;18:1016.

20. Orasan; Olga Hilda; Urian LC, George; Breaban, Iulia; Stefan, Andreea Maria; Secara, Sorina Cezara, et al. Thrombocytopenia in end-stage renal disease and chronic viral hepatitis B or C. Journal of Mind and Medical Sciences 2018;5:236-43.

21. Ando M, Iwamoto Y, Suda A, Tsuchiya K, Nihei H. New insights into the thrombopoietic status of patients on dialysis through the evaluation of megakaryocytopoiesis in bone marrow and of endogenous thrombopoietin levels. Blood 
2001;97:915-21.

22. Huynh T, Zhang J, Hu KQ. Hepatitis C Virus clearance by direct-acting antiviral results in rapid resolution of hepatocytic injury as indicated by both alanine aminotransferase and aspartate aminotransferase normalization. J Clin Transl Hepatol 2018;6:258-63.

23. Ozer Etik D, Ocal S, Boyacioglu AS. Hepatitis C infection in hemodialysis patients: A review. World J Hepatol 2015; 7:88595.

24. Badalamenti S, Catania A, Lunghi G, Covini G, Bredi E, Brancaccio D, et al. Changes in viremia and circulating interferon during hemodialysis in hepatitis $\mathrm{C}$ virus-positive patients: only coincidental phenomena? American Journal of Kidney Diseases 2003;42:143-50.

25. Chakravarti A, Dogra G, Verma V, Srivastava AP. Distribution pattern of HCV genotypes \& its association with viral load. Indian J Med Res. 2011;133:326-31.

26. Marinaki S, Boletis JN, Sakellariou S, Delladetsima IK. Hepatitis $\mathrm{C}$ in hemodialysis patients. World J Hepatol 2015;7:548-58.

27. Huang JW, Yen CJ, Pai MF, Wu KD, Tsai TJ, Hsieh BS. Association between serum aspartate transaminase and homocysteine levels in hemodialysis patients. American Journal of Kidney Diseases 2002;40:1195-201.

28. Sombolos KI, Fragidis SK, Bamichas GI, Hatsiou VN, Bantis CK, Tsantekidou HS, et al. Dogma disputed: postdialysis increase of aminotransferase values cannot be attributed to an inhibitor removal by hemodialysis. ASAIO Journal 2012;58:612-5.

29. Poordad F, Schiff ER, Vierling JM, Landis C, Fontana RJ, Yang R, et al. Daclatasvir with sofosbuvir and ribavirin for hepatitis $\mathrm{C}$ virus infection with advanced cirrhosis or post-liver transplantation recurrence. Hepatology 2016;63:1493-505.

30. Knop V, Hoppe D, Welzel T, Vermehren J, Herrmann E, Vermehren A, et al. Regression of fibrosis and portal hypertension in $\mathrm{HCV}$-associated cirrhosis and sustained virologic response after interferon-free antiviral therapy. Journal of Viral Hepatitis 2016;23:994-1002.

31. Lee YA, Friedman SL. Reversal, maintenance or progression: what happens to the liver after a virologic cure of hepatitis C? Antiviral Res 2014;107:23-30.

32. van der Meer AJ, Berenguer M. Reversion of disease manifestations after $\mathrm{HCV}$ eradication. J Hepatol 2016;65:S95-S108.

33. Dolmazashvili E, Abutidze A, Chkhartishvili N, Karchava M, Sharvadze L, Tsertsvadze T. Regression of liver fibrosis over a 24-week period after completing direct-acting antiviral therapy in patients with chronic hepatitis $\mathrm{C}$ receiving care within the national hepatitis $\mathrm{C}$ elimination program in Georgia: results of hepatology clinic HEPA experience. Eur J Gastroenterol Hepatol 2017;29:1223-30.

34. Shiha G, Soliman R, Mikhail N, Ibrahim A, Serwah A-H, Khattab M. Changes in hepatic fibrosis stages after achieving SVR following direct-acting anti-viral treatment: a prospective study. Gastroenterol Hepatol 2020;2:39-48.

35. Chen Yi Mei SLG, Thompson AJ, Christensen B, Cunningham G, McDonald L, Bell S, et al. Sustained virological response halts fibrosis progression: a long-term follow-up study of people with chronic hepatitis C infection. PLoS One 2017;12:e0185609-e. 